University of South Carolina

Scholar Commons

$1-1-2010$

\title{
Comparison of Stabilization Methods for Fixed-Speed Wind Generator Systems
}

Mohammod Ali

University of South Carolina - Columbia, alimo@engr.sc.edu

Bin Wu

Ryerson University

Follow this and additional works at: https://scholarcommons.sc.edu/elct_facpub

Part of the Electrical and Computer Engineering Commons

Publication Info

Published in IEEE Transactions on Power Delivery, Volume 25, 2010, pages 323-331.

http://ieeexplore.ieee.org/xpl/Recentlssue.jsp?punumber=61

(C) 2010 by IEEE

This Article is brought to you by the Electrical Engineering, Department of at Scholar Commons. It has been accepted for inclusion in Faculty Publications by an authorized administrator of Scholar Commons. For more information, please contact digres@mailbox.sc.edu. 


\title{
Comparison of Stabilization Methods for Fixed-Speed Wind Generator Systems
}

\author{
Mohd. Hasan Ali, Senior Member, IEEE, and Bin Wu, Fellow, IEEE
}

\begin{abstract}
Static Synchronous Compensator (STATCOM), Pitch control system, Braking Resistor (BR), and Superconducting Magnetic Energy Storage (SMES) have recently been reported as stabilization methods for fixed-speed wind generator systems. Although the individual technologies are well documented, a comparative study of these systems has not been reported so far. This paper aims to fill in the gap, and provides a comprehensive analysis of these stabilization methods for fixed-speed wind generator systems. The analysis is performed in terms of transient stability enhancement, controller complexity, and cost. A novel feature of this work is that the transient stability analysis of wind generator system is carried out considering unsuccessful reclosing of circuit breakers. Simulation results demonstrate that the SMES is the most effective means of transient stability enhancement and minimization of both power and voltage fluctuations, but it is the most expensive device. The STATCOM is a cost-effective solution for transient stability enhancement and minimization of voltage fluctuations. The BR is the simplest in structure and a cost-effective solution for transient stability enhancement. The pitch controller is the cheapest one, but its response is much slower than that of other devices.
\end{abstract}

Index Terms-Braking resistor (BR), pitch controller, stabilization of fixed-speed wind generator, static synchronous compensator (STATCOM), superconducting magnetic energy storage (SMES), unsuccessful reclosing.

\section{INTRODUCTION}

$\mathbf{T}$ HE depletion of conventional energy resources and the perpetual increase in demand for energy in today's industrialized world have necessitated the need to explore nonconventional energy sources and to find optimum methods of exploiting these alternative energy potentials. Among these, wind energy today ranks as one of the most promising renewable energy technologies for generating electric power due to its free, clean, and renewable character, besides having an extremely large potential. In recent years, extensive research and development activities have been in progress universally on the development, manufacturing, and erection of cost-competitive, energy-efficient, and reliable wind energy conversion systems (WECS). Modern wind turbine generation systems (WTGS) usually are variable speed WTGS. Nevertheless, over the former years, fixed-speed WTGS were installed in large proportions in power grids. As wind parks have a lifetime over 20 years, it is still a matter of

Manuscript received May 29, 2009. First published December 04, 2009; current version published December 23, 2009. Paper no. TPWRD-00266-2009.

M. H. Ali is with the Department of Electrical Engineering, University of South Carolina, Columbia, SC 29208 USA (e-mail: hasan@cec.sc.edu).

B. Wu is with the Department of Electrical and Computer Engineering, Ryerson University, George Vari Engineering \& Computing Center, Toronto, ON M5B 1Z2, Canada,

Digital Object Identifier 10.1109/TPWRD.2009.2035423 interest to investigate the interaction of fixed-speed WTGS with power system [1]. Fixed-speed WTGS utilize squirrel cage induction generators directly connected to the power grid. However, induction generators have stability problems similar to the transient stability of synchronous machines [2]-[5]. Therefore, it is important to analyze the transient stability of power systems including wind power stations.

The research on the selection of a suitable device for the stabilization of fixed-speed wind generator is a matter of interest. In literatures, Static Synchronous Compensator (STATCOM) [6]-[9] is reported to stabilize the fixed-speed wind generator. Braking resistor (BR) has been recognized and used as a cost-effective measure for transient stability control of synchronous generators for a long time [10], [11]. According to some recent reports [12]-[16], BR can be used for wind generator stabilization as well. A controller of the blade pitch angle of windmill is, in general, equipped with wind turbines. Although the main purpose of the pitch controller is to maintain output power of wind generator at the rated level when wind speed is above the rated speed, it can enhance the transient stability of wind generator by controlling the rotor speed [4], [17]-[20]. Superconducting magnetic energy storage (SMES) is a large superconducting coil capable of storing electric energy in the magnetic field generated by DC current flowing through it. The real power as well as the reactive power can be absorbed (charging) by or released (discharging) from the SMES coil according to system power requirements. Since the successful commissioning test of the BPA 30 MJ unit [21], SMES systems have received much attention in power system applications, such as, diurnal load demand leveling, frequency control, automatic generation control, uninterruptible power supplies, etc. Recently, research is being conducted to investigate the effectiveness of SMES as a tool for the stabilization of grid connected wind generator system [22]-[26].

Thus it is seen that the above mentioned methods of stabilization for fixed-speed wind generators are recently being given emphasis. However, although the individual technologies are well documented, a comparative study of these systems has not been reported so far. This paper aims to fill in the gap, and provides a comprehensive analysis of these stabilization methods for fixed-speed wind generator systems. The analysis is performed in terms of transient stability enhancement, controller complexity, and cost. A novel feature of this work is that the transient stability analysis is carried out considering permanent fault i.e., unsuccessful reclosing of circuit breakers. It is hoped this study would help the readers understand the relative effectiveness of the stabilization methods and provides a guideline for selecting a suitable technique for the stabilization of wind energy systems. 


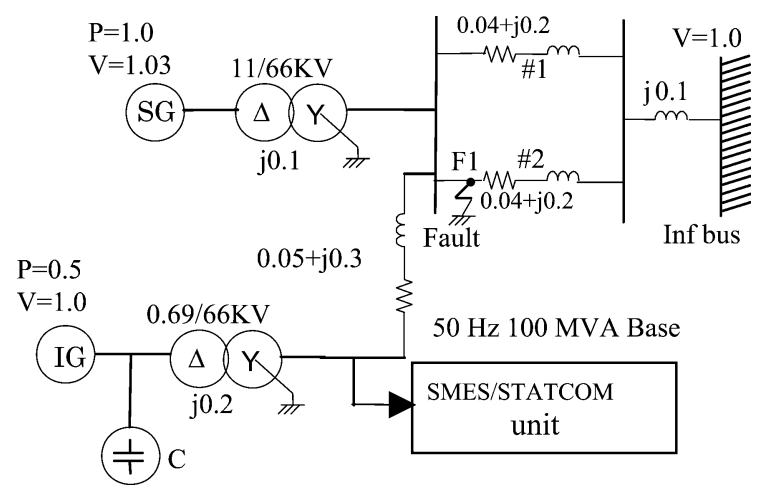

Fig. 1. Power system model.

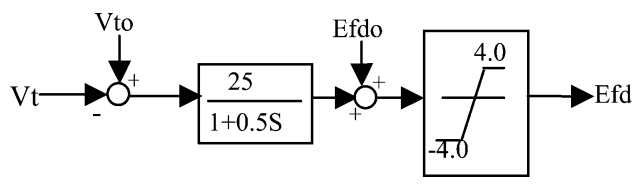

Fig. 2. AVR model.

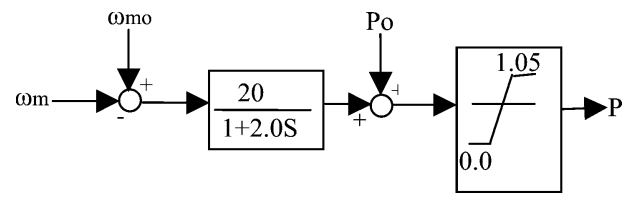

Fig. 3. GOV model.

The organization of this paper is as follows: Section II describes the model system for the proposed study. Section III describes the modeling of the wind turbine. Sections IV-VII explain the control schemes of the SMES, STATCOM, braking resistor, and pitch controller, respectively. Section VIII analyzes the simulation results. Finally, Section IX provides conclusions regarding this work.

\section{MOdEL SYSTEM}

The model system shown in Fig. 1 has been used in this work. The model system consists of one synchronous generator (100 MVA, SG), and one wind turbine generator (50 MVA induction generator, IG), which are delivering power to an infinite bus through a transmission line with two circuits. Though a wind power station is composed of many generators practically, it is considered to be composed of a single generator with the total power capacity in this paper. There is a local transmission line with one circuit between the main transmission line and a transformer at the wind power station. A capacitor $\mathrm{C}$ is connected to the terminal of the wind generator to compensate the reactive power demand for the induction generator at the steady state. The value of $\mathrm{C}$ has been chosen so that the power factor of the wind power station becomes unity when it is generating the rated power $(\mathrm{P}=0.5, \mathrm{~V}=1.0)$. The Automatic Voltage Regulator (AVR) and Governor (GOV) control system models shown in Figs. 2 and 3, respectively, for the synchronous generator are
TABLE I

GENERATOR PARAMETERS

\begin{tabular}{c|c|c|c}
\hline \multicolumn{2}{c|}{ SG } & \multicolumn{2}{c}{ IG } \\
\hline $\mathrm{MVA}$ & 100 & $\mathrm{MVA}$ & 50 \\
\hline $\mathrm{r}_{\mathrm{a}}[\mathrm{pu}]$ & 0.003 & $\mathrm{r}_{1}[\mathrm{pu}]$ & 0.01 \\
\hline $\mathrm{X}_{\mathrm{a}}[\mathrm{pu}]$ & 0.13 & $\mathrm{x}_{1}[\mathrm{pu}]$ & 0.18 \\
\hline $\mathrm{X}_{\mathrm{d}}[\mathrm{pu}]$ & 1.2 & $\mathrm{X}_{\mathrm{mu}}[\mathrm{pu}]$ & 10.0 \\
\hline $\mathrm{X}_{\mathrm{q}}[\mathrm{pu}]$ & 0.7 & $\mathrm{r}_{2}[\mathrm{pu}]$ & 0.015 \\
\hline $\mathrm{X}_{\mathrm{d}}^{\prime}[\mathrm{pu}]$ & 0.3 & $\mathrm{x}_{2}[\mathrm{pu}]$ & 0.12 \\
\hline $\mathrm{X}_{\mathrm{q}}^{\prime}[\mathrm{pu}]$ & 0.22 & $\mathrm{H}[\mathrm{sec}]$ & 0.75 \\
\hline $\mathrm{X}_{\mathrm{d}}[\mathrm{pu}]$ & 0.22 & & \\
\hline $\mathrm{X}_{\mathrm{q}}^{\prime \prime}[\mathrm{pu}]$ & 0.25 & & \\
\hline $\mathrm{T}^{\prime}{ }_{\mathrm{do}}[\mathrm{sec}]$ & 5.0 & & \\
\hline $\mathrm{T}^{\prime \prime}{ }_{\mathrm{do}}[\mathrm{sec}]$ & 0.04 & & \\
\hline $\mathrm{T}^{\prime \prime}{ }_{\mathrm{qo}}[\mathrm{sec}]$ & 0.05 & & \\
\hline $\mathrm{H}[\mathrm{sec}]$ & 2.5 & & \\
\hline
\end{tabular}

considered in this work. Table I shows the synchronous generator parameters [27] as well as induction generator parameters [28] used in this work.

\section{Modeling OF WIND TURBINE}

The modeling of wind turbine rotor is complicated. According to the blade element theory [29], modeling of blade and shaft needs complicated and lengthy computations. Moreover, it also needs detailed and accurate information about rotor geometry. For that reason, considering only the electrical behavior of the system, a simplified method of modeling of the wind turbine blade and shaft is normally used. In general, the mathematical relation for the mechanical power extraction from the wind can be expressed as follows [29]:

$$
P_{w}=0.5 * \rho * \pi * R^{2} * V_{w}^{3} * C_{p}(\lambda, \beta)
$$

where $P_{w}$ is the extracted power from the wind, $\rho$ is the air density $\left[\mathrm{kg} / \mathrm{m}^{3}\right], R$ is the blade radius $[\mathrm{m}], V_{w}$ is the wind velocity $[\mathrm{m} / \mathrm{s}]$, and $C_{p}$ is the power coefficient which is a function of both tip speed ratio, $\lambda$, and blade pitch angle, $\beta$ [deg].

In this work, the MOD-2 model [19] is considered for $C_{p}-\lambda$ characteristics, which is represented by the following equations, and shown in Fig. 4:

$$
\begin{aligned}
\lambda & =\frac{\left(\omega_{R} * R\right)}{V_{W}} \\
C_{p} & =\frac{1}{2}\left(\lambda-0.022 \beta^{2}-5.6\right) e^{-0.17}
\end{aligned}
$$

where $\omega_{R}$ is the rotational speed $[\mathrm{rad} / \mathrm{s}]$.

\section{CONTROL SCHEME OF SMES}

An SMES device is a DC current device that stores energy in the magnetic field. The DC current flowing through a superconducting wire in a large magnet creates the magnetic field. Fig. 5 shows the basic configuration [30] of the proposed SMES unit, which consists of a Wye-Delta $66 \mathrm{KV} / 0.77 \mathrm{KV}$ transformer, 


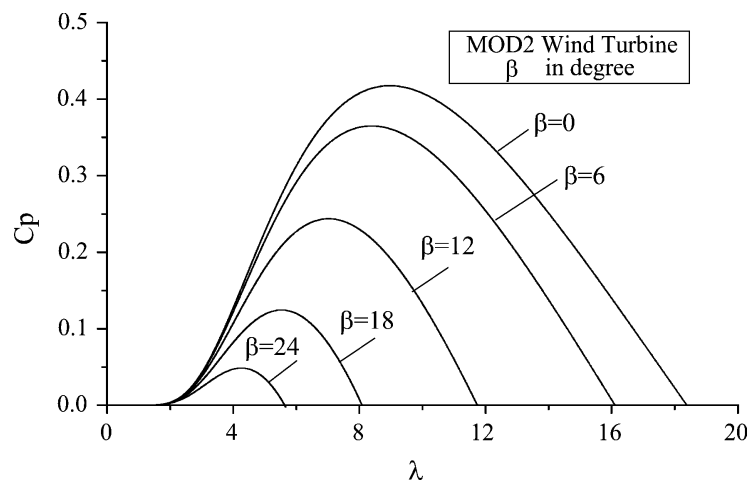

Fig. 4. $C_{P}-\lambda$ curves for different pitch angles.

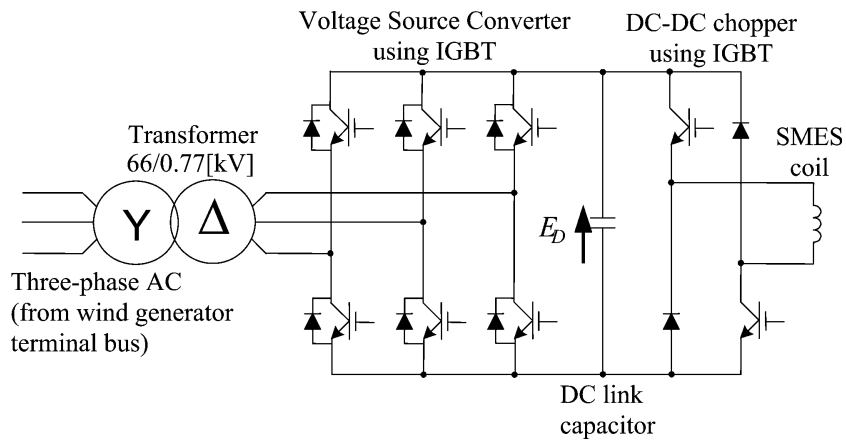

Fig. 5. Basic configuration of SMES system.

a 6-pulse PWM rectifier/inverter (50 MVA) using insulatedgate-bipolar-transistor (IGBT), a two quadrant DC-DC chopper using IGBT, and a superconducting coil or inductor of $0.24 \mathrm{H}$. The PWM converter and the DC-DC chopper are linked by a dc link capacitor of $60 \mathrm{mF}$. The detailed explanation of the voltage source converter (VSC) and two-quadrant DC-DC chopper are available in [25].

For an SMES system, the inductively stored energy ( $E$ in Joule) and the rated power ( $P$ in Watt) are commonly the given specifications for SMES devices, and can be expressed as follows:

$$
\begin{aligned}
& E=\frac{1}{2} L_{s m} I_{s m}^{2} \\
& P=\frac{d E}{d t}=L_{s m} I_{s m} \frac{d I_{s m}}{d t}=V_{s m} I_{s m}
\end{aligned}
$$

where $L_{s m}$ is the inductance of the coil, $I_{s m}$ is the DC current flowing through the coil, and $V_{s m}$ is the voltage across the coil. The SMES unit is located at the wind generator terminal bus. The proposed SMES has the rating of $50 \mathrm{MW}, 0.05 \mathrm{MWh}$.

\section{A. PWM Voltage Source Converter}

The pulsewidth modulation (PWM) voltage source converter (VSC) provides a power electronic interface between $\mathrm{AC}$ power system and superconducting coil. In the PWM generator, the sinusoidal reference signal is phase modulated by means of the phase angle, $\alpha$, of the VSC output ac voltage. The phase angle, $\alpha$, is determined from the outputs of the Proportional-Integral

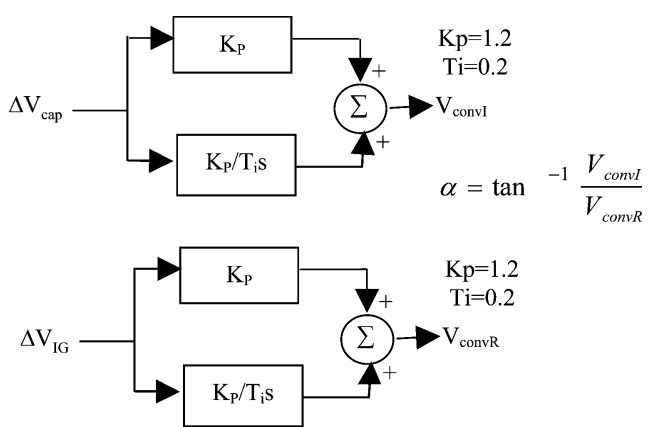

Fig. 6. Block diagrams of PI controller to determine $\alpha$.

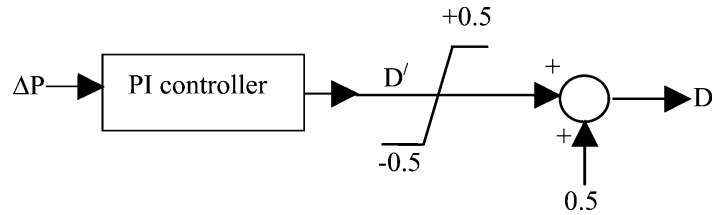

Fig. 7. Control of chopper duty cycle.

(PI) controllers as shown in Fig. 6, where $\Delta \mathrm{V}_{\text {cap }}$ and $\Delta \mathrm{V}_{\text {IG }}$ indicate the capacitor voltage deviation and terminal voltage deviation of the induction generator, respectively [25]. The PI controller parameters are determined by trial and error in order to obtain the best system performance. In this work, the amplitude modulation index of the sinusoidal reference signal is chosen 1.0. The modulated sinusoidal reference signal is compared with the triangular carrier signal in order to generate the gate signals for the IGBT's. The frequency of the triangular carrier signal is chosen $450 \mathrm{~Hz}$. The DC voltage across the capacitor is 1000 Volt, which is kept constant throughout by the 6-pulse PWM converter.

\section{B. Two-Quadrant DC-DC Chopper}

The superconducting coil is charged or discharged by adjusting the average (i.e., DC) voltage across the coil to be positive or negative values by means of the DC-DC chopper duty cycle, D, controlled by a conventional PI controller as shown in Fig. 7, where $\Delta \mathrm{P}$ indicates the real power deviation of induction generator. When the duty cycle is larger than 0.5 or less than 0.5 , the coil is either charging or discharging respectively. When the unit is on standby, the coil current is kept constant, independent of the storage level, by adjusting the chopper duty cycle to $50 \%$, resulting in the net voltage across the superconducting winding to be zero. In order to generate the gate signals for the IGBT's of the chopper, the PWM reference signal is compared with the saw tooth carrier signal. The frequency of the saw tooth carrier signal for the chopper is chosen $100 \mathrm{~Hz}$.

\section{CONTROL SCHEME OF STATCOM}

A STATCOM is a second-generation flexible ac transmission system controller based on a self-commutating solid-state voltage source inverter. However, it can only absorb/inject reactive power, and consequently is limited in the degree of freedom and sustained action [30]. As can be seen from Fig. 5, excluding 




Fig. 8. Location of the BR.

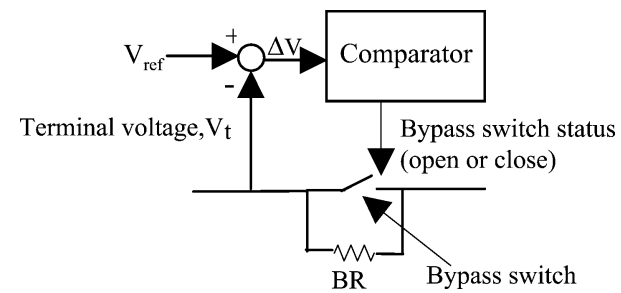

Fig. 9. BR control method.

the DC-DC chopper and SMES coil the remaining components represent the basic two-level STATCOM which is used in this work.

\section{CONTROL SCHEME OF BR}

This paper uses a series dynamic braking resistor [12] of $1.0 \mathrm{pu}(43.56 \mathrm{ohm})$ value for wind generator stabilization. The BR concept aims to contribute directly to the balance of active power during a fault. It can be done by dynamically inserting a resistor in the generation circuit, increasing the voltage at the terminals of the generator and thereby mitigating the destabilizing depression of electrical torque and power during the fault period. The location of the BR in the power system model of Fig. 1 is shown through Fig. 8.

The BR would operate with its parallel switch closed under normal conditions, bypassing the braking resistor. Voltage depression below a selected set-point would lead to near-instantaneous tripping of the switch. Current would then flow through the inserted resistor dissipating power. The braking resistor would remain in the circuit as long as the terminal voltage of the wind generator is below a threshold value. When the wind generator system becomes stable, the switch would close and the circuit would be restored to its normal state. Fig. 9 shows the control methodology of the braking resistor. According to the control method, if $\Delta \mathrm{V}$ (difference in voltage) is positive, then the bypass switch is open, while if $\Delta \mathrm{V}$ is negative or zero, then the bypass switch is closed. Thus, a closed loop control of the braking resistor is realized. It is important to note here that the bypass switch is based on the thyristor-controlled technology.

\section{Control Scheme of Pitch Method}

Although the main purpose of using a pitch controller with wind turbine is to maintain a constant output power at the terminal of the generator when the wind speed is over the rated speed, it can enhance the transient stability of wind generator by controlling the rotor speed. The pitch control system model of

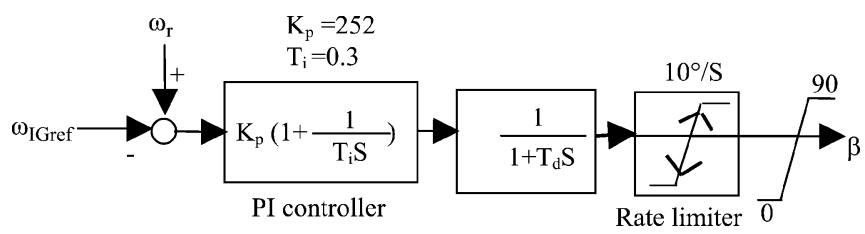

Fig. 10. Pitch control system model.

the wind turbine used in this work is shown in Fig. 10. The time constant, $\mathrm{T}_{\mathrm{d}}$, of the control system is 3.0 [sec]. The parameters of the PI controller, $K_{p}=252$ and $T_{i}=0.3$, are determined by trial and error in order to obtain the best system performance.

\section{Simulation Results AND Discussions}

In this work, simulations are performed by using Electro-Magnetic Transients Program (EMTP) [31]. Simulations are carried out considering two cases: (1) a balanced (3LG: Three-phase-to-ground) fault occurs at point F1 near the synchronous generator at line \#2 as shown in the system model, and (2) unsuccessful reclosure of circuit breakers occurs due to a permanent fault at point $\mathrm{F} 1$ near the synchronous generator at line \#2. The time step and simulation time have been chosen as $50.0 \mu \mathrm{sec}$ and $10.0 \mathrm{sec}$, respectively.

In order to clearly understand the effect of the stabilization methods, several performance indices, namely, vlt (pu.sec), $\operatorname{spd}(p u . \mathrm{sec})$, pow $(p u . \mathrm{sec})$, and $\operatorname{ang}(\mathrm{deg} . \mathrm{sec})$, as shown below in (4)-(7), respectively, are considered

$$
\begin{aligned}
v l t(p u . \sec ) & =\int_{0}^{T}|\Delta V| d t \\
\operatorname{spd}(p u . \sec ) & =\int_{0}^{T}\left|\Delta \omega_{r}\right| d t \\
\operatorname{pow}(p u . \sec ) & =\int_{0}^{T}|\Delta P| d t \\
\operatorname{ang}(\operatorname{deg} . \sec ) & =\int_{0}^{T}|\Delta \delta| d t .
\end{aligned}
$$

In (4) to (7), $\Delta V, \Delta \omega_{r}, \Delta P$ and $\Delta \delta$ denote the terminal voltage deviation of wind generator, the speed deviation of wind generator, the real power deviation of wind generator, and the load angle deviation of synchronous generator, respectively, and $T$ is the simulation time of $10.0 \mathrm{sec}$. The lower the values of the indices, the better the system's performance.

\section{A. Comparison in Terms of Transient Stability Enhancement During Successful Reclosing}

In this case, it is considered that the fault occurs at $0.1 \mathrm{sec}$, circuit breakers on the faulted lines are opened at $0.2 \mathrm{sec}$, and circuit breakers are closed again at $1.0 \mathrm{sec}$. It is assumed that the circuit breaker clears the line when the current through it crosses the zero level. Although actually the wind speed is randomly varying, during the short time span of the analysis of the transient stability the variation of wind speed can be considered negligible, and it is therefore assumed in this paper that the wind speed is constant at $11.8 \mathrm{~m} / \mathrm{s}$.

Table II shows the values of the performance indexes in case of successful reclosing of circuit breakers. It is seen that all 
TABLE II

VALUES OF INDEXES FOR STABILIZATION METHODS DURING SUCCESSFUL RECLOSING.

\begin{tabular}{c|c|c|c|c|c}
\hline \multirow{2}{*}{$\begin{array}{c}\text { Index } \\
\text { parameters }\end{array}$} & \multicolumn{5}{|c}{ Values of indices } \\
\cline { 2 - 6 } & $\begin{array}{c}\text { Pitch } \\
\text { method }\end{array}$ & $\begin{array}{c}\text { BR } \\
\text { method }\end{array}$ & $\begin{array}{c}\text { STATCOM } \\
\text { method }\end{array}$ & $\begin{array}{c}\text { SMES } \\
\text { method }\end{array}$ & $\begin{array}{c}\text { Without } \\
\text { controller }\end{array}$ \\
\hline vlt (pu.sec) & 1.73 & 0.32 & 0.26 & 0.22 & 4.46 \\
\hline spd (pu.sec) & 0.48 & 0.02 & 0.02 & 0.02 & 7.81 \\
\hline pow (pu.sec) & 2.86 & 0.10 & 0.18 & 0.16 & 4.63 \\
\hline ang (deg.sec) & 75.04 & 56.45 & 48.54 & 46.00 & 103.05 \\
\hline
\end{tabular}

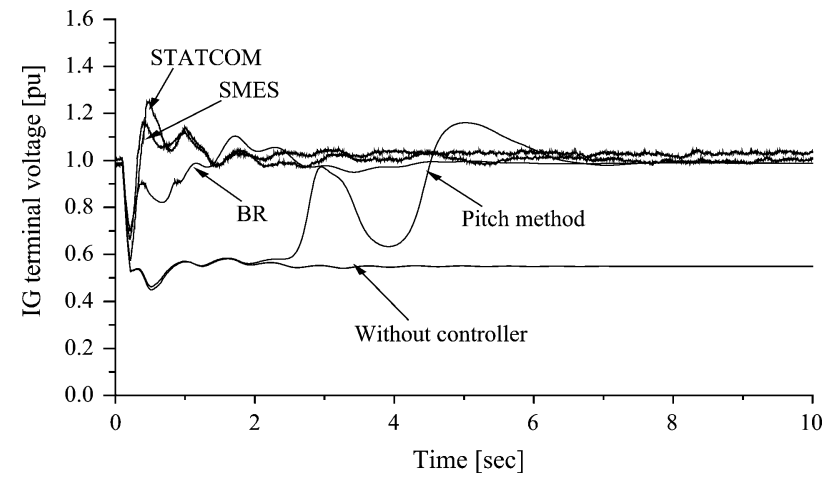

Fig. 11. Responses of IG terminal voltage.

methods are effective in transient stability enhancement, however, from the viewpoint of the index pow $(p u . s e c)$, the BR is the best, while with respect to the index $\operatorname{spd}(p u$. sec $)$, the BR, STATCOM, and SMES exhibit the same performance. From the perspective of $v l t(p u$. sec) and ang (deg.sec), the performance of the SMES is the best, and the STATCOM is better than the BR. The pitch method exhibits the worst performance with respect to all indices.

Fig. 11 shows the responses of the IG terminal voltage. It is seen that the IG terminal voltage returns back to its steady state value due to the use of any of the devices of the SMES, STATCOM, BR, and pitch controller. Fig. 12 shows the responses of the IG rotor speed. It is seen that because of the use of any of the devices of the SMES, STATCOM, BR, and pitch controller, IG becomes stable. Fig. 13 shows the responses of the IG real power. In this case it is seen that any of the devices of the SMES, STATCOM, BR, and pitch controller can maintain the IG real power at the rated level. Fig. 14 shows the responses of the SG load angle. It is clearly seen that the synchronous generator is transiently stable when any of the devices of the SMES, STATCOM, BR, and pitch controller is used. This fact also indicates that the SMES, STATCOM, BR, and pitch controller can make the entire power system stable in case of successful reclosing of circuit breakers.

However, although each of the devices of the SMES, STATCOM, BR, and pitch controller can make the wind generator stable, it is evident from the simulation results that the performance of the SMES is the best. The STATCOM and BR provide almost the same performance. The response of the pitch controller is much slower than that of the SMES, STATCOM, and BR.

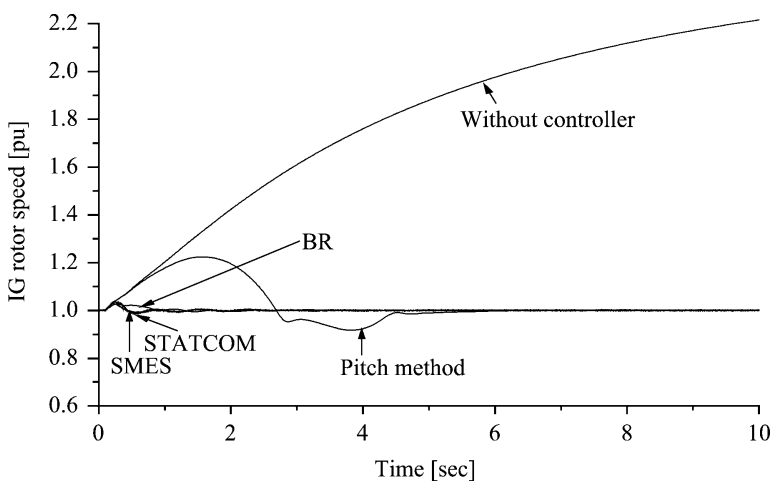

Fig. 12. Responses of IG rotor speed.

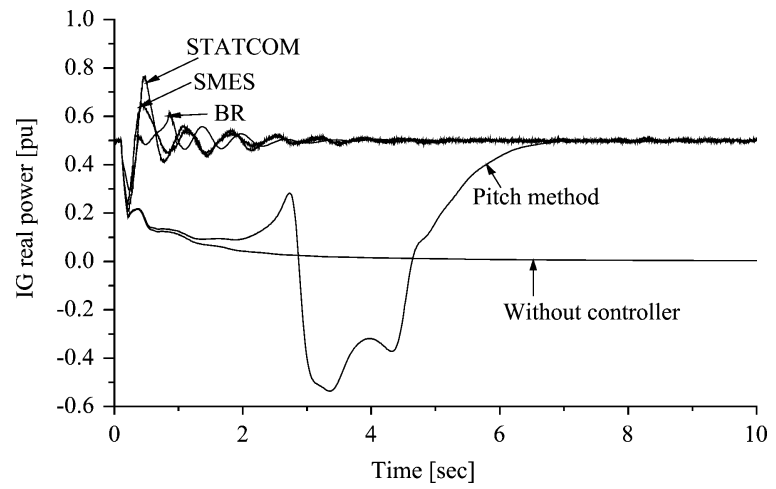

Fig. 13. Responses of IG real power.

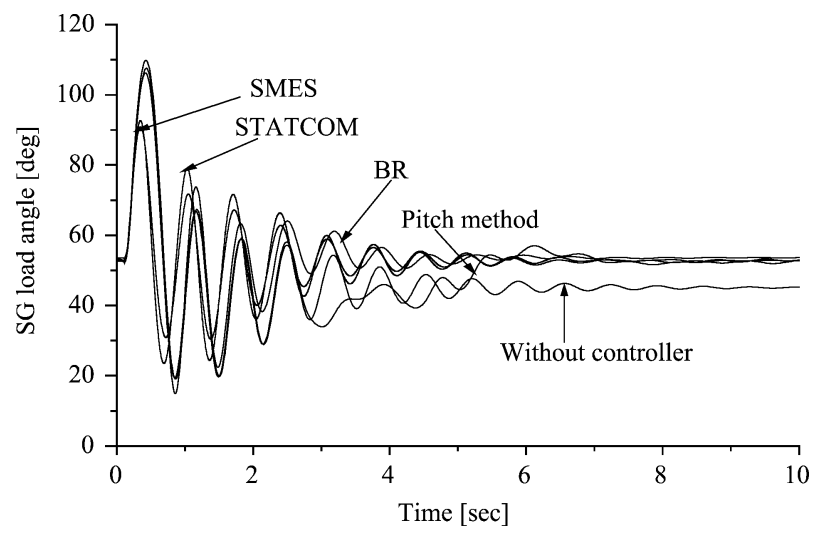

Fig. 14. Responses of SG load angle.

\section{B. Comparison in Terms of Transient Stability Enhancement During Unsuccessful Reclosing}

During the simulation, it is considered that the reclosing of circuit breakers is unsuccessful due to a permanent fault. Therefore, the circuit breakers are reopened after $0.1 \mathrm{sec}$ of the reclosing time. The other simulation conditions are the same as the previous one.

The values of the performance indexes are shown in Table III. From the indexes it is seen that the SMES, STATCOM, and BR can stabilize both the wind generator and synchronous generator. In other words, these three methods can stabilize the overall system well. The pitch method can stabilize the wind generator, but cannot stabilize the synchronous generator as evident from the index ang (deg.sec), that is, the pitch method 
TABLE III

VALUES OF INDEXES FOR STABILIZATION METHODS DURING UNSUCCESSFUL RECLOSING.

\begin{tabular}{c|c|c|c|c|c}
\hline \multirow{2}{*}{$\begin{array}{c}\text { Index } \\
\text { parameters }\end{array}$} & \multicolumn{5}{|c}{ Values of indices } \\
\cline { 2 - 6 } & $\begin{array}{c}\text { Pitch } \\
\text { method }\end{array}$ & $\begin{array}{c}\text { BR } \\
\text { method }\end{array}$ & $\begin{array}{c}\text { STATCOM } \\
\text { method }\end{array}$ & $\begin{array}{c}\text { SMES } \\
\text { method }\end{array}$ & $\begin{array}{c}\text { Without } \\
\text { controller }\end{array}$ \\
\hline vlt (pu.sec) & 3.09 & 0.41 & 0.55 & 0.51 & 5.22 \\
\hline spd (pu.sec) & 0.67 & 0.04 & 0.04 & 0.04 & 8.04 \\
\hline pow (pu.sec) & 2.61 & 0.20 & 0.28 & 0.23 & 4.70 \\
\hline ang (deg.sec) & 24045.36 & 164.05 & 134.11 & 115.80 & 28779.39 \\
\hline
\end{tabular}

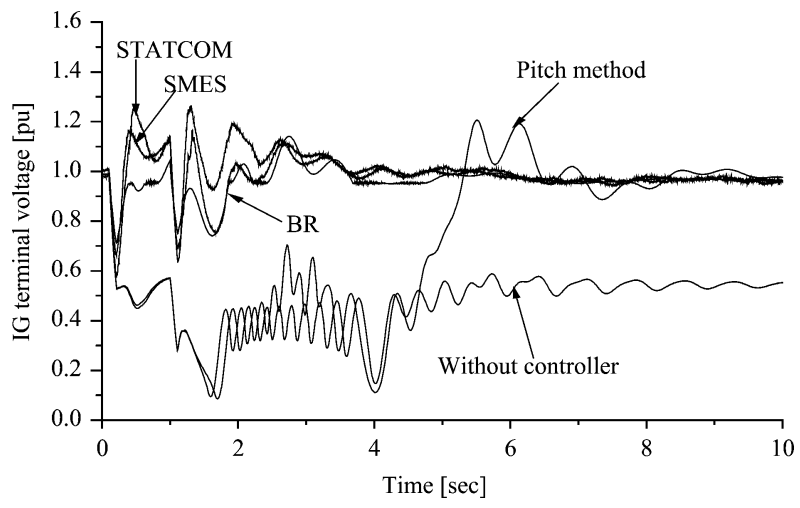

Fig. 15. Responses of IG terminal voltage.

cannot stabilize the overall system in case of unsuccessful reclosing of circuit breakers. Also, from the perspective of the index $a n g(\mathrm{deg} . \mathrm{sec})$, the performance of the SMES is the best, while from the viewpoints of $v l t(p u . \mathrm{sec})$ and $p o w(p u . \mathrm{sec})$, the performance of the BR is the best, and the SMES is better than STATCOM. From the viewpoint of $\operatorname{spd}(p u$. sec), the performance of the SMES, STATCOM, and BR is the same. Again, with respect to all indices, the performance of the pitch method is the worst.

The responses of the IG terminal voltage, IG rotor speed, and IG real power are shown in Figs. 15-17, respectively. It is clear that any of the devices of the SMES, STATCOM, BR, and pitch controller can stabilize the wind generator system in case of unsuccessful reclosing of circuit breakers. However, the performance of the SMES is the best, while the pitch controller exhibits the worst performance. Also, the response of the pitch controller is much slower than that of the SMES, STATCOM, and BR. The performance of the STATCOM and BR is almost the same. Fig. 18 shows the responses of the SG load angle. It is seen that the pitch controller cannot stabilize the synchronous generator, but the SMES, STATCOM, and BR can make the synchronous generator transiently stable well. In other words, the pitch method cannot stabilize the overall system, while the other three methods can make the entire power system stable well.

\section{Comparison in Terms of Minimization of Power and Voltage Fluctuations}

In the previous sections, comparison of SMES, STATCOM, BR and pitch system was made on the basis of transient stability enhancement of wind generator considering constant wind speed. However, wind speed is randomly varying, and consequently output power and terminal voltage of wind generator

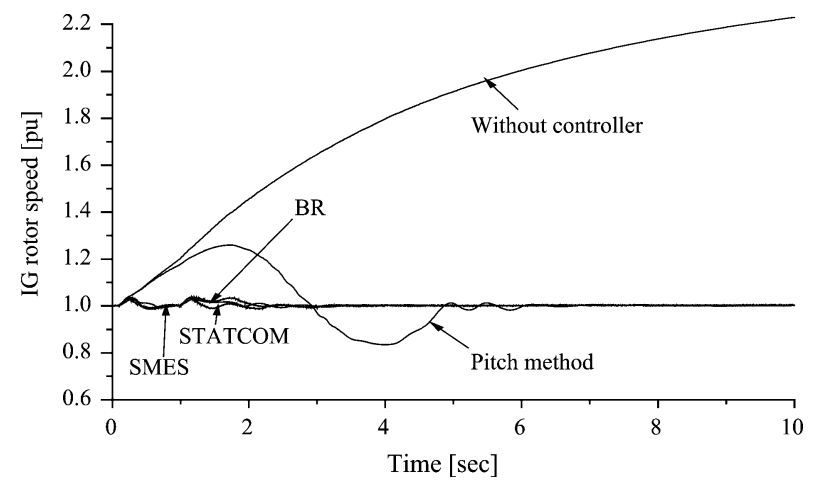

Fig. 16. Responses of IG rotor speed.

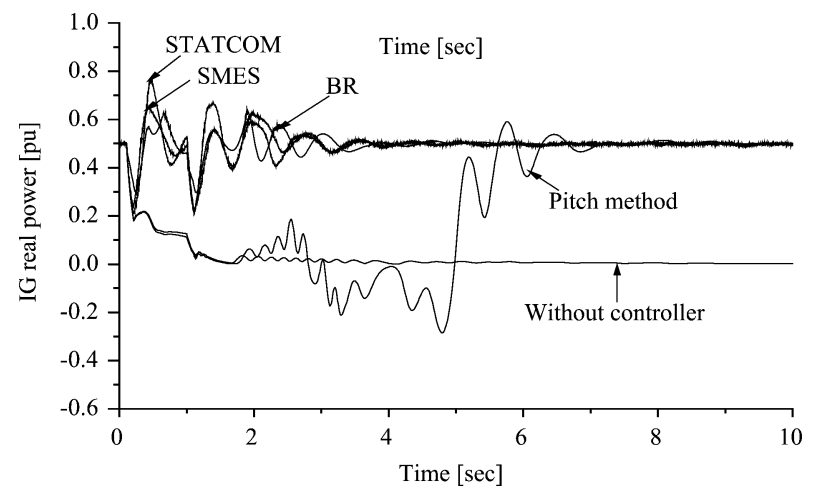

Fig. 17. Responses of IG real power.

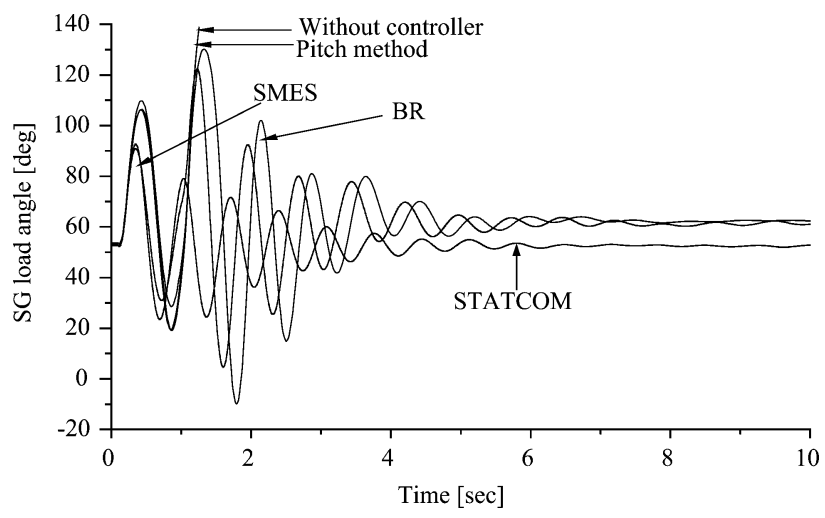

Fig. 18. Responses of SG load angle.

are fluctuating. Thus, the minimization of fluctuations of power and voltage of fixed-speed wind generator is an important issue. Although the purpose of this work is not to analyze the issue of minimization of fluctuations of power and voltage, it can be stated based on some reports [24]-[26] that the SMES is able to minimize well voltage and power fluctuations of fixed-speed wind generators. This is due to the fact that the SMES is able to control both active and reactive powers. The STATCOM can only control the reactive power, but not the active power. Thus, the STACOM is able only to minimize voltage fluctuations of wind generator [7]. The BR can only consume active power, but cannot generate active power and also cannot control reactive power. Thus, the BR is not able to minimize power and voltage fluctuations of wind generator. The pitch control method cannot 
TABLE IV

OVERALl COMPARISON OF STABILIZATION METHOdS.

\begin{tabular}{|c|c|c|c|c|}
\hline \multirow[t]{2}{*}{ Criteria } & \multicolumn{4}{|c|}{ Stabilization methods } \\
\hline & Pitch control & BR & STATCOM & SMES \\
\hline $\begin{array}{l}\text { Ability to control active } \\
\text { and reactive powers }\end{array}$ & Can control only active power & $\begin{array}{l}\text { Can consume only } \\
\text { active power }\end{array}$ & $\begin{array}{l}\text { Can control only } \\
\text { reactive power }\end{array}$ & $\begin{array}{l}\text { Can control both active } \\
\text { and reactive powers }\end{array}$ \\
\hline $\begin{array}{l}\text { Transient stability } \\
\text { enhancement during } \\
\text { successful reclosing }\end{array}$ & $\begin{array}{c}\text { Can stabilize the overall system, } \\
\text { but its response is slower } \\
\text { compared to BR, STATCOM, and } \\
\text { SMES }\end{array}$ & $\begin{array}{l}\text { Can stabilize the overall } \\
\text { system and effective }\end{array}$ & $\begin{array}{c}\text { Can stabilize the overall } \\
\text { system and effective }\end{array}$ & $\begin{array}{l}\text { Can stabilize the overal } \\
\text { system and the most } \\
\text { effective }\end{array}$ \\
\hline $\begin{array}{c}\text { Transient stability } \\
\text { enhancement during } \\
\text { unsuccessful reclosing }\end{array}$ & $\begin{array}{l}\text { Can stabilize the wind generator } \\
\text { but cannot stabilize the } \\
\text { synchronous generator, that is, } \\
\text { cannot stabilize the overall system }\end{array}$ & $\begin{array}{l}\text { Can stabilize the overall } \\
\text { system and effective }\end{array}$ & $\begin{array}{c}\text { Can stabilize the overall } \\
\text { system and effective }\end{array}$ & $\begin{array}{l}\text { Can stabilize the overal } \\
\text { system and the most } \\
\text { effective }\end{array}$ \\
\hline $\begin{array}{l}\text { Minimization of power } \\
\text { and voltage fluctuations }\end{array}$ & $\begin{array}{l}\text { Able to minimize only power } \\
\text { fluctuations }\end{array}$ & $\begin{array}{c}\text { Not able to minimize } \\
\text { power and voltage } \\
\text { fluctuations }\end{array}$ & $\begin{array}{l}\text { Able to minimize only } \\
\text { voltage fluctuations }\end{array}$ & $\begin{array}{c}\text { Able to minimize both } \\
\text { power and voltage } \\
\text { fluctuations }\end{array}$ \\
\hline Controller complexity & More complex than BR & Simplest & $\begin{array}{l}\text { More complex than } \\
\text { pitch system }\end{array}$ & Most complex \\
\hline Manufacturing cost & Cheapest & $\begin{array}{l}\text { Costlier than pitch } \\
\text { control }\end{array}$ & Costlier than BR & Most expensive \\
\hline
\end{tabular}

minimize voltage fluctuations, but can smooth power fluctuations of wind generator well [32], [33]. Thus, it is found that among SMES, STATCOM, BR, and pitch control method, only the SMES is able to minimize both power and voltage fluctuations of wind generators.

\section{Comparison in Terms of Controller Complexity}

From the viewpoint of controller structure, the SMES is the most complex one as it has two control aspects, namely the VSC control and the DC-DC chopper control, while the BR has the simplest control structure. Between STATCOM and pitch controller, the STATCOM has more complex structure.

\section{E. Comparison in Terms of Cost}

Although the actual costs of the SMES, STATCOM, BR, and pitch control system are not known, it may be conjectured that the total installation and maintenance cost of the SMES is the highest, because the major components of the SMES system are a transformer, a voltage source converter using IGBT, a DC link capacitor, a DC-DC chopper using IGBT, a large superconducting coil cooled by liquid helium, and a refrigerator that maintains the temperature of the helium coolant. Thus, the number of necessary components of the SMES system is bigger than that of any of the devices of STATCOM, BR, and pitch control system. On the other hand, the pitch control system might have the lowest cost. The STATCOM consists of a transformer, a voltage source converter using IGBT and a capacitor, while the BR consists of a linear resistor and a thyristor switch. Therefore, between STATCOM and BR, the STATCOM might be costlier.

\section{F. Overall Comparison}

Table IV provides a summary of the above comparative analyses, which could be used for decision making purposes. It can be stated that, although the pitch control system is the cheapest solution, but its response in transient stability enhancement as well as power fluctuations minimization is slow. As a consequence, the pitch control system cannot be considered as an effective solution. The braking resistor can be considered as a very simple and cost-effective solution from the viewpoints of the transient stability enhancement of wind generator system in case of both successful and unsuccessful reclosing of circuit breakers. From the perspective of transient stability enhancement as well as voltage fluctuations minimization, STATCOM provides a cost-effective solution. SMES is the most expensive device; however, from the viewpoints of transient stability enhancement and minimization of both power and voltage fluctuations, SMES is the most effective solution. It is worth noting that, due to its salient properties such as very fast response, high efficiency, capability of control of real power and reactive power, etc., SMES system is gradually getting increasing interest in the field of power systems. It is hoped that its potential advantages and environmental benefits will make SMES units a viable alternative for energy storage and management devices in the future [34], [35]. And although at present the cost of a SMES unit appears somewhat high, continued research and development is likely to bring the price down and make the technology appear even more attractive.

One point to note here is that in this work the controller parameters have been determined by the trial and error approach, and the parameters are tuned very carefully so that the best system performance can be obtained. Although only the results corresponding to the severest fault case (3LG fault) are shown in the paper, the designed parameters are tested in case of other faults also, like double-line-to-ground (2LG) fault, line-to-line (2LS) fault, and single-line-to-ground (1LG) fault in the system, and it is found that the system performance is good and effective. Thus, it can be emphasized that the designed controller parameters are robust and stable.

\section{CONCLUSION}

This paper provides a comparative analysis of SMES, STATCOM, braking resistor, and pitch control methods on the basis of transient stability enhancement, controller complexity, and manufacturing cost of fixed-speed wind energy systems. A 
novel feature of this work is that the transient stability analysis is conducted considering unsuccessful reclosing of circuit breakers. The following can be concluded.

1) The pitch control system is the cheapest solution for wind generator stabilization in case of successful reclosing of circuit breakers and power fluctuations minimization, but its response is slow. As a consequence, the pitch control system cannot be considered as an effective stabilization means for wind generator system.

2) The braking resistor method can be considered as a very simple and cost-effective solution from the viewpoints of the transient stability enhancement of wind generation systems in case of both successful and unsuccessful reclosing of circuit breakers.

3) From the perspective of transient stability enhancement in case of both successful and unsuccessful reclosing of circuit breakers and voltage fluctuations minimization, STATCOM provides a cost-effective solution.

4) SMES is the most expensive device. However, from the viewpoints of transient stability enhancement in case of both successful and unsuccessful reclosing of circuit breakers, and minimization of both power and voltage fluctuations, SMES is the most effective solution.

This study helps the readers understand the relative effectiveness of the stabilization methods and provides a guideline for selecting a suitable technique for the stabilization of wind energy systems.

\section{REFERENCES}

[1] A. Sumper, O. G. Bellmunt, A. S. Andreu, R. V. Robles, and J. R. Duran, "Response of fixed speed wind turbines to system frequency disturbances," IEEE Trans. Power Syst., vol. 24, no. 1, pp. 181-192, Feb. 2009.

[2] G. S. Stavrakakis and G. N. kariniotakis, "A general simulation algorithm for the accurate assessment of isolated diesel-wind turbines systems interaction. Part I: A general multimachine power system model," IEEE Trans. Energy Convers., vol. 10, no. 9, pp. 577-583, Sep. 1995.

[3] G. S. Stavrakakis and G. N. kariniotakis, "A general simulation algorithm for the accurate assessment of isolated diesel-wind turbines systems interaction. Part II: Implementation of the algorithm and casestudies with induction generators," IEEE Trans. Energy Convers., vol. 10, no. 9, pp. 584-590, Sep. 1995.

[4] J. Tamura, T. Yamazaki, M. Ueno, Y. Matsumura, and S. Kimoto, "Transient stability simulation of power system including wind generator by PSCAD/EMTDC," in Proc. IEEE Porto Power Tech, 2001, vol. 4, Paper no. EMT-108.

[5] E. S. Abdin and W. Xu, "Control design and dynamic performance analysis of a wind turbine-induction generator unit," IEEE Trans. Energy Convers., vol. 15, no. 3, pp. 91-96, Mar. 2000.

[6] Z. S. Saoud, M. L. Lisboa, J. B. Ekanayake, N. Jenkins, and G. Strbac, "Application of STATCOMs to wind farms," Proc. IEE Gener. Transm. Distrib., vol. 145, no. 5, pp. 511-516, Sep. 1998.

[7] S. M. Muyeen, M. A. Mannan, M. H. Ali, R. Takahashi, T. Murata, and J. Tamura, "Stabilization of wind turbine generator system by STATCOM," IEEJ Trans. Power Energy, vol. 126, no. 10, pp. 1073-1082, Oct. 2006.

[8] M. Aten, J. Martinez, and P. J. Cartwright, "Fault recovery of a wind farm with fixed speed induction generators using a STATCOM," Wind Eng., vol. 29, no. 4, pp. 365-375, 2005.

[9] H. Gaztanaga, I. E. Otadui, D. Ocnasu, and S. Bacha, "Real-time analysis of the transient response improvement of fixed-speed wind farms by using a reduced-scale STATCOM prototype," IEEE Trans. Power Syst., vol. 22, no. 2, pp. 658-666, May 2007.
[10] M. H. Ali, T. Murata, and J. Tamura, "Effect of coordination of optimal reclosing and fuzzy controlled braking resistor on transient stability during unsuccessful reclosing," IEEE Trans. Power Syst., vol. 21, no. 3, pp. 1321-1330, Aug. 2006.

[11] M. H. Ali, T. Murata, and J. Tamura, "The effect of temperature rise of the fuzzy logic-controlled braking resistors on transient stability," IEEE Trans. Power Syst., vol. 19, no. 2, pp. 1085-1095, May 2004.

[12] A. Causebrook, D. J. Atkinson, and A. G. Jack, "Fault ride-through of large wind farms using series dynamic braking resistors (March 2007)," IEEE Trans. Power Syst., vol. 22, no. 3, pp. 966-975, Aug. 2007.

[13] W. Freitas, A. Morelato, and W. Xu, "Improvement of induction generator stability using braking resistors," IEEE Trans. Power Syst., vol. 19, no. 2, pp. 1247-1249, May 2004.

[14] X. Wu, A. Arulampalam, C. Zhan, and N. Jenkins, "Application of a static reactive power compensator (STATCOM) and a dynamic braking resistor (DBR) for the stability enhancement of a large wind farm," Wind Eng., vol. 27, no. 2, pp. 93-106, 2003.

[15] A. Arulampalam, M. Barnes, N. Jenkins, and J. B. Ekanayake, "Power quality and stability improvement of a wind farm using STATCOM supported with hybrid battery energy storage," Proc. IEE Gener. Transm. Distrib., vol. 153, no. 6, pp. 701-110, Nov. 2006.

[16] K. Rajambal, B. Umamaheswari, and C. Chellamuthu, "Electrical braking of large wind turbines," Renewable Energy, vol. 30, no. 15, pp. 2235-2245, Dec. 2005.

[17] P. M. Anderson and A. Bose, "Stability simulation of wind turbine systems," IEEE Trans. Power Apparat. Syst., vol. PAS-102, no. 12, pp. 3791-3795, Dec. 1983.

[18] J. Tamura, T. Yamazaki, R. Takahashi, S. Yonaga, Y. Matsumura, and H. Kubo, "Analysis of transient stability of wind generators," in Proc. Int. Conf. Electrical Machines (ICEM) 2002, Aug. 2002, Paper 148.

[19] J. G. Slootweg, S. W. D. de Haan, H. Polinder, and W. L. Kling, "General model for representing variable speed wind turbines in power system dynamics simulations," IEEE Trans. Power Syst., vol. 18, no. 1, pp. 144-151, Feb. 2003.

[20] S. M. Muyeen, M. H. Ali, R. Takahashi, T. Murata, and J. Tamura, "Transient stability enhancement of wind generator by a new logical pitch controller," IEEE Trans. Power Energy, vol. 126, no. 8, pp. 742-752, Aug. 2006.

[21] H. J. Boenig and J. F. Hauer, "Commissioning tests of the bonneville power administration $30 \mathrm{MJ}$ superconducting magnetic energy storage unit," IEEE Trans. Power Apparat. Syst., vol. PAS-104, no. 2, pp. 302-309, Feb. 1985.

[22] S. C. Tripathy, M. Kalantar, and R. Balasubramanian, "Dynamics and stability of wind and diesel turbine generators with superconducting magnetic energy storage on an isolated power system," IEEE Trans. Energy Convers., vol. 6, pp. 579-585, Dec. 1991.

[23] S. Nomura, Y. Ohata, T. Hagita, H. Tsutsui, S. Tsuji-Iio, and R. Shimada, "Wind farms linked by SMES systems," IEEE Trans. Appl. Supercond., vol. 15, no. 2, pp. 1951-1954, Jun. 2005.

[24] T. Kinjo, T. Senjyu, N. Urasaki, and H. Fujita, "Terminal-voltage and output-power regulation of wind-turbine generator by series and parallel compensation using SMES," Proc. IEE Gener. Transm. Distrib., vol. 153, no. 3, pp. 276-282, May 2006.

[25] M. H. Ali, T. Murata, and J. Tamura, "Minimization of fluctuations of line power and terminal voltage of wind generator by fuzzy logic-controlled SMES," Int. Rev. Electr. Eng. (IREE), vol. 1, no. 4, pp. 559-566, Oct. 2006.

[26] M. H. Ali, T. Murata, and J. Tamura, "Wind generator stabilization by PWM voltage source converter and chopper controlled SMES," in Proc. Record ICEM, Sep. 2006, CD-ROM.

[27] J. Tamura, Y. Shima, R. Takahashi, T. Murata, Y. Tomaki, S. Tominaga, A. Sakahara, and S. Suzuki, "Transient stability analysis of wind generator during short circuit faults," presented at the Keynote Lecture, 3rd Int. Conf. Syst., Signals \& Devices (SSD’05), Sousse, Tunisia, Mar. 21-24, 2005.

[28] J. Tamura, S. Yonaga, Y. Matsumura, and H. Kubo, "A consideration on the voltage stability of wind generators," Trans. IEE Jpn., vol. 122-B, no. 10, pp. 1129-1130, Oct. 2002.

[29] S. Heier, Grid Integration of Wind Energy Conversion System. New York: Wiley, 1998.

[30] "IEEE task force on benchmark models for digital simulation of FACTS and custom-power cntrollers, T\&D committee, detailed modeling of superconducting magnetic energy storage (SMES) system," IEEE Trans. Power Del., vol. 21, pp. 699-710, Apr. 2006.

[31] EMTP Theory Book. Japan: EMTP Committee, 1994. 
[32] S. M. Muyeen, M. H. Ali, R. Takahashi, T. Murata, and J. Tamura, "Wind generator output power smoothing by using pitch controller," Int. Rev. Electr. Eng. (IREE), vol. 2, no. 3, pp. 310-321, Jun. 2007.

[33] T. Senjyu, R. Sakamoto, N. Urasaki, T. Funabashi, H. Fujita, and H. Sekine, "Output power leveling of wind turbine generator for all operating regions by pitch angle control," IEEE Trans. Energy Convers., vol. 21, pp. 467-475, Jun. 2006.

[34] Y.-S. Lee, "Decentralized suboptimal control of power systems with superconducting magnetic energy storage units," Int. J. Power Energy Syst., vol. 21, no. 2, pp. 87-96, 2001.

[35] P. D. Baumann, "Energy conservation and environmental benefits that may be realized from superconducting magnetic energy storage," IEEE Trans. Energy Conversion, vol. 7, no. 6, pp. 253-259, Jun. 1992.

Mohd. Hasan Ali (SM'08) received the B.Sc.Eng. degree from Rajshahi University of Engineering and Technology (RUET), Bangladesh, in 1995, and the M.Sc.Eng. and Dr.Eng. degrees from Kitami Institute of Technology, Kitami, Japan, in 2001 and 2004, respectively, all in electrical and electronic engineering.

He served as a Lecturer in Electrical and Electronic Engineering Deparment, RUET, Bangladesh, from 1995 to 2004, and became an Assistant Professor in 2004. He was a Postdoctoral Research Fellow under the Japan Society for the Promotion of Science (JSPS) Program at the Kitami Institute of Technology, Japan, from November 2004 to January 2007. He also worked as a Research Professor in Electrical Engineering Department of Changwon National University, South Korea from February 2007 to December 2007. He was a Postdoctoral
Research Fellow with the Electrical and Computer Engineering Department of Ryerson University, Canada, from January 2008 to June 2009. Curently he is working as an Assistant Professor with the Electrical Engineering Department of the University of South Carolina, Columbia. His main field of interest includes power system stability and control, application of power electronics to power systems and electrical machines, renewable energy systems, superconducting magnetic energy storage (SMES) systems, and FACTS.

Dr. Ali is a senior member of the IEEE Power and Energy Society (PES).

Bin Wu (F'08) received the M.A.Sc. and Ph.D. degrees in electrical and computer engineering from the University of Toronto, Toronto, ON, Canada, in 1989 and 1993 , respectively.

After being with Rockwell Automation Canada as a Senior Engineer, he joined Ryerson University, Toronto, where he is currently a Professor with the Department of Electrical and Computer Engineering and NSERC/Rockwell Industrial Research Chair in Power Electronics and Electric Drives. His research interests include high-power converters, variable speed drives, renewable energy systems, and flexible AC transmission systems.

Dr. Wu was a recipient of the Gold Medal of the Governor General of Canada, the Premier's Research Excellence Award, the Ryerson Sarwan Sahota Distinguished Scholar Award, the Ryerson Research Chair Award, and the NSERC Synergy Award for Innovation. He is a Registered Professional Engineer in the Province of Ontario, Canada, and an Associate Editor of IEEE TRANSACTIONS ON POWER ELECTRONICS. 